Saudi Journal of Biomedical Research

Abbreviated Key Title: Saudi J Biomed Res ISSN 2518-3214 (Print) |ISSN 2518-3222 (Online)

\title{
Molecular Characterization of Human Rotavirus Strains Circulating Among Children Less Than 5 Years Attended With Diarrhea to Mohammed Alamin Hamid Pediatric Hospital, Khartoum
}

Waseem Sameer Kwami ${ }^{1}$, Shamsoun Khamis Kafi ${ }^{2}$, Mahdi Hassan Mahmoud ${ }^{3}$, Abdul Hakam Hassan Aldigeal ${ }^{4}$, Mosab Nouraldein Mohammed Hamad ${ }^{5 *}$

${ }^{1}$ Department of Microbiology, Faculty of Medical Laboratory Sciences, University of Shendi, Sudan

${ }^{2}$ Department of Microbiology, Faculty of Medical Laboratory Sciences, The National Ribat University, Khartoum, Sudan

${ }^{3}$ Department of Microbiology, Faculty of Medical Laboratory Sciences, Alzaiem Alazhari University, Khartoum, Sudan

${ }^{4}$ Department of Microbiology, Faculty of Medical Laboratory Sciences, Albutana University, Khartoum, Sudan

${ }^{5}$ Phylum of Medical Parasitology, Faculty of Medical Laboratory Sciences, Elsheikh Abdallah Elbadri University, Berber City, Sudan

DOI: $10.36348 /$ sjbr.2020.v05i06.005 $\quad$ | Received: 02.06.2020 | Accepted: 19.06.2020 | Published: 26.06 .2020

*Corresponding author: Mosab Nouraldein Mohammed Hamad

Email: musab.noor13@gmail.com

\section{Abstract}

Diarrhea remains the first leading causes of children mortality worldwide specially in developing countries, lead to approximately (1.87) million deaths yearly.There is a global agreement that rotaviruses are the single prominent causative agents of childhood diarrhea illnesses worldwide. The objective of this work was to characterize human rotavirus strains circulating among children attended with diarrhea to Mohammed Alamin Hamid Pediatric Hospital using molecular methods. 150 fecal specimens from infants less than 5 years were collected and analyzed. The samples were investigated for presence of rotavirus using antigen based enzyme immune-sorbent assay (ELISA), genotyping was carried out by RT-PCR to determine virus genotypes using VP7 gene specific primer sets. Rotavirus was detected in stool of $42(28.7 \%)$ out of 150 total children. The study revealed that the percentage of (Rotavirus Ag positive) children was $(29.3 \%)$ in males which is nearly equal to the percentage of Rotavirus Ag positive children in females (26.6\%) but this difference in gender was significant statistically insignificant.

Keywords: Molecular characterizations, Rotavirus strains, Children, Khartoum, Sudan.

Copyright @ 2020: This is an open-access article distributed under the terms of the Creative Commons Attribution license which permits unrestricted use, distribution, and reproduction in any medium for non-commercial use (NonCommercial, or CC-BY-NC) provided the original author and source are credited.

\section{INTRODUCTION}

Diarrhea still be one of the leading infants mortality causes globally, lead to approximately (1.87) million deaths each year [1].

There is a global agreement that rotaviruses are the leading etiologic agents of severe diarrhea illnesses of infants and young children globally. Although repeated infections of rotavirus occur throughout an person's lifetime, symptomatic infections take place commonly during the first two years of life [2].

Rotavirus lead to about (30-50) \% of diarrheal illnesses in children and the frequency of rotavirus problems has remained increased despite improvements in sanitation. an justification for this may be the improved hygienic practices and oral rehydration therapy have yielded in high decline of hospitalization from parasitic and bacterial diarrhea than hospitalization from rotavirus diarrhea. The most effective public health strategy to reduce rotavirus disease danger is vaccination [3].

Globally, rotaviruses lead to more than (125) million cases of diarrhea in infants less than age of (5) years with the greatest incidence in children between (6-24) month and lead to approximately $(527,000)$ deaths each year world-wide, more than $(85) \%$ of those deaths tale place in developing countries in Africa and Asia [4].

World health organization (WHO) sponsored review of rotavirus studies declared that $(20-70) \%$ of hospitalizations and (20) \% of diarrhea mortalaties were due to rotavirus. Rota virus infection may lead to a spectrum of illnesses ranging from mild sub clinical to severe and on occasion fatal Dehydrating diseases. The clinical presentation is vomitingfor three days and 
fivedays of watery diarrhea with moderate fever following incubation period of two days [5].

Two vaccines are available for rotavirus, a single strain live attenuated human rotavirus vaccine and multi-strain bovine-human reasserting vaccines. WHO recommends the incorporation of rotavirus vaccines in all countries routine vaccination schedules, regions where deaths from diarrhea account for $\geq(10)$ $\%$ of mortality among children less than (5) years of age, the application of rotavirus vaccine is highly recommended. The Efficacy of these vaccines has ranged from (80 to 98) \% in industrial countries, including Latin America, and (39 to 77) \% in developing countries, such as Africa and Asia [5].

Rotaviruses are members of family Reoviridae, genus Rotavirus and they have three important antigenic specificities: group, subgroup, and serotype. Depending on group specificity which is determined predominantly by (VP6) glycoprotein, rotaviruses divided into seven groups $(A, B, C, D, E, F$, and $G)$. Human rotavirus $(H R V)$-related infections are mainly due to group $\mathrm{A}$, and less commonly due to group $\mathrm{B}$ or $\mathrm{C}$, The group A rotavirus genome consists of eleven segments of double-stranded RNA ( $d s R N A)$ encoding 6 structural viral proteins $(V P 1, V P 2, V P 3$, $V P 4, V P 6$, and VP7) and 6 nonstructural proteins (NSP1, NSP2, NSP3, NSP4, NSP5, NSP6) enclosed in 3 layer protein capsid, consisting of a protein core, an inner protein capsid, and an outer protein capsid [6].

Subgroup specificity, which is conferred by (VP6), has been applied for characterizing the antigenic characters of Rotavirus strains in epidemiologic researches. Most $(H R V s)$ belong to either subgroup I or subgroup II [2].

Rotavirus can be classified also into many serotypes using antisera for neutralization assays and genotyped on the base of two outer capsid proteins, the glycoprotein VP7 (determining G genotypes) and the spike protein VP4 (determining $\mathrm{P}$ genotypes). These two proteins produce neutralizing antibodies in the host and encoded by VP7 and VP4 genes of rotavirus, respectively [6].

Currently, $(32 \quad P)$ genotypes and $(23 \quad G)$ genotypes are known, based on nucleotide sequence variations; however, few genotypes are known to cause infection in humans [7].

The incidence and distribution of $G$ and $P$ genotypes that lead to disease in humans may vary by year and geographical location. Epidemiological researches worldwide have documented the main human $\mathrm{G}$ types are $(G 1, G 2, G 3, G 4$, and $G 9)$, which combined with the $\mathrm{P}$ types $(P 8),(P 4)$, and $(P 6)$, responsible for more than $(80) \%$ of rotavirus gastroenteritis episodes globally.Knowledge about the diversity andprevalence of $\mathrm{G}$ and $\mathrm{P}$ types circulatingin the population is essential for the formulationof an adequate vaccine as well asfor the assessment of protection after vaccination [8].

(G1) rotavirus is the most frequent genotype, and it has been found in frequencies ranging from $(36$ to 74$) \%$ in varioust regions of the world. (G1P8) strains make approximately (65) \% of rotavirus types identified globally [6].

\section{METHOD \\ Specimen}

$5 \mathrm{ml}$ of stool specimen was collected from every participant child in clean, broad mouth, leak proof container. Then the specimens were stored at ($70^{\circ} \mathrm{C}$ ) for further use.

\section{Dilution of Faecal Samples}

A $10 \%$ suspension of stool prepared from each sample by adding approximately of semisolid feces (small pea sized portion) or $(100 \mu \mathrm{l})$ of liquid sample into $(1 \mathrm{ml})$ sample diluents. The mixture was mixed thoroughly, then transferred to well labeled container using a pipette. The mixed preparation was stored at (2$8^{\circ} \mathrm{C}$ ) for up to (8 days) prior to testing.

ELISA Procedure for detection of Rotavirus antigen

- The reagents were allowed to reach the room temperature within (30 minutes).

- The foil pouch was removed and the required number of microplate strips was taken and placed into a microplate strip holder.

- One well was used for each of the negative and positive control and one well for each specimen.

- From the diluted stool specimen 2 drops $(100 \mu \mathrm{l})$ were added, and also the controls were added into the specific microwells.

- 2 drops $(100 \mu \mathrm{l})$ of conjugate were added to each microwell.

- The plate was covered and incubated at $\left(20-30^{\circ} \mathrm{C}\right)$ for (60 minutes).

- $\quad$ The automated washer was adjusted to complete (5 wash cycles). After the final wash, the plate was inverted and tapped on absorbent paper to get rid from the last traces of wash buffer.

- 2 drops (or $100 \mu \mathrm{l}$ ) of substrate were added to every microwell.

- The plate was covered and the microwells were incubated at $\left(20-30^{\circ} \mathrm{C}\right)$ for (10 minutes).

- The Substrate reaction was stopped by adding 2 drops $(100 \mu \mathrm{l})$ of stop solution to every microwell and mixed before reading the results.

- The final coloured product was Read spectrophotometrically at $(450 \mathrm{~nm})$

\section{Reading and Interpretation of the Results}

The test results were interpreted according to manufacturer as follow: 
Positive: clinical sample absorbance value > the cutoff value.

Negative: clinical sample absorbance value < the cutoff value.

Equivocal: clinical sample absorbance value within (0.010 absorbance units) of the cut-off value. These samples should be retested or the patient resampled.

\section{Extraction and purification of viral RNA}

The RNA of Rotavirus was extracted from $(150 \mu \mathrm{l})$ of $(10 \%)$ stool suspension in phosphate buffer saline. The suspension was mixed then centrifuged at $(10,000 \mathrm{~g})$ for $(10$ minutes $)$. The yielded supernatant aspirated and subjected to the viral RNA extraction using Viral Gene-spin(TM) Viral DNA/RNA Extraction Kit, according to the following manufacturer's instructions (Intron Biotechnology, inc. KOREA).

- $\quad(150 \mu \mathrm{l})$ of the supernatant was added to $(250 \mu \mathrm{l})$ of lysis buffer and mixed, then mixed by vortexing for ( 15 seconds). The mixture is then incubated for (10 minutes) at room temperature.

- A $(350 \mu \mathrm{l})$ of binding buffer was added and mixed well by vortexing gently. Aspin column was then located on the provided $(2 \mathrm{ml})$ collection tube.

- The lysate was then loaded on the column, centrifuged at $(13000 \mathrm{rpm})$ for (1 minute). The solution was discarded from the collection tube and the column was placed again in the same $(2 \mathrm{ml})$ collection tube.

- A $(500 \mu \mathrm{l})$ of washing buffer A was added and centrctifuged at (13000 rpm) for (1 minute). The solution was discarded from the collection tube and the column was located again in the same $(2 \mathrm{ml})$ collection tube.

- A $(500 \mu \mathrm{l})$ of washing buffer B was added and centrifuged at (13000 rpm) for (1 minute). The solution was discarded from the collection tube and the column was located again in the same $2 \mathrm{ml}$ collection tube and centrifuged for (1 minute) at (13000 rpm).

- The column was placed in RNase-free $(1.5 \mathrm{ml})$ microcentrifuge tube and a $(60 \mu 1)$ of Elution buffer was added directly onto the membrane and incubated at room temperature for 1 minute and centrifuged at (13000 rpm).

- The purified RNA were eluted in $(60 \mu 1)$ of RNaseand DNase- free water and soonly stored at $\left(-70^{\circ} \mathrm{C}\right)$ prior to use.

\section{Reverse Transcription Protocol}

$8 \mu 1$ of total dsRNA, $3 \mu 1$ of DEPC-treated water, and $1 \mu \mathrm{l}$ of random hexamer $(0.02 \mu \mathrm{g} \mu \mathrm{l})$ were added to an RT tube on ice, adding up to a total volume of $12 \mu \mathrm{l}$ per tube. The tubes were then incubated at $80^{\circ} \mathrm{C}$ for 3 minutes and later chilled on ice for $(2$ minutes) after that they were span briefly. The following reagents were then added to the tubes, $5 \mu 1$ of $5 \times$ RT buffer, $1 \mu \mathrm{l}$ of RNAse inhibitor $(20 \mathrm{u} / \mu \mathrm{l}), 2 \mu \mathrm{l}$ of $10 \mathrm{mMdNTP}$ and $1 \mu \mathrm{l}$ of reverse transcriptase (200 $\mathrm{u} / \mu \mathrm{l})$ adding up to a volume of $20 \mu \mathrm{l}$ per tube. The tubes were then incubated at $\left(37^{\circ} \mathrm{C}\right)$ for $(90$ minutes) then heated to $\left(94^{\circ} \mathrm{C}\right)$ for ( 2 minutes), then chilled on ice for ( 2 minutes) and layer span briefly. All cDNA samples were stored at $\left(-20^{\circ} \mathrm{C}\right)$ ready for use.

\section{Amplification of cDNA by multiplex PCR}

cDNA Amplification was done using Maxime PCR preMix Kit following manufacturer's protocol illustrated below. A master mix constituted of $4 \mu 110$ Mm dNTP's, $0.3 \mu \mathrm{l}$ Tag polymerase, $4 \mu \mathrm{l} \times 10 \mathrm{Tag}$ buffer, $2.4 \mu \mathrm{l} 25 \mathrm{Mm} \mathrm{MgCl}_{2}$ and30 $\mu \mathrm{l} \mathrm{dH}_{2} \mathrm{O}$ was prepared whereby, the volume of each reagent was multiplied by the number of samples. $40 \mu \mathrm{l}$ of the master mix were then added to each tube containing cDNA and span down briefly before placing in PCR block. Then ran using the following program.

Table-1: Thermo cycler program for amplification of cDNA

\begin{tabular}{|l|l|l|l|}
\hline Cycling profile & Temperature & Duration & No of cycles \\
\hline Denaturation & $95^{\circ} \mathrm{c}$ & 30 seconds & 35 \\
\hline Annealing & $50-65^{\circ} \mathrm{c}$ & 30 seconds & 35 \\
\hline Extension & $72^{\circ} \mathrm{C}$ & 1 minute & 35 \\
\hline Final Extension & 72 & 7 minutes & 35 \\
\hline
\end{tabular}

(Anita et al., 2010 [8])

\section{Gel Documentation}

Visualization of the $P C R$ products were done in $(2 \%)$ Agarose gel mixed with $(0.5) \mu \mathrm{g} / \mathrm{ml}$ Ethidium bromide staining, prepared by dissolving $(0.5) \mathrm{g}$ of agarose powder in (25) $\mathrm{ml}$ of $1 \mathrm{X} T B E$ buffer and heated at $(65)^{\circ} \mathrm{C}$ in microwave until the agarose dissolved completely, then allow to cool at room temperature and (2) $\mu 1$ Ethidium bromides was added. The comb was then placed appropriately in the electrophoresis tray and then slowly the gel was poured and allowed to set for (30) $\min$ for solidification. In a clean Eppendorf tube (10) $\mu 1$ of (100) bpDNA ladder and PCR product was loaded on the gel. Gel-electrophoresis was performed at
(100V) and (60) Am for (30-45) minutes. Pictures were taken by gel documentation system (Gel mega, digital camera and software in a computer).

\section{Rotavirus G Genotyping}

$\mathrm{G}$ genotyping was done by seminested multiplex PCR. In the first cycle of PCR, a 1062 bp fragment of VP7 gene was amplified with forward primer:

Beg 9 (5'-GGC TTT AAA AGA GAG AAT TTC CGTCTG G-3') and reverse primer:

End 9 (5'-GGT CAC ATC ATA CAA TTC TAA TCT AAG-3') 
The second cycle of typing PCR incorporated the Beg 9 consensus primer and $G$ type specific primers in order to amplify G1(746 bp), G2 (657bp), G3(582bp), and G9(306bp) types. The amplicons were separated by electrophoresis $2 \%$ agrose gel and visualized and photographed after staining with ethidium bromide.

A master mix was prepared by mixing $(10 \mathrm{Mm}$ dNTP's, $25 \mathrm{Mm} \mathrm{MgCl}_{2}$ ), primers Beg to a clean eppendorf tube, while multiplying the volume of each reagent by the number of the samples. To ensure the quality of the results negative control where primers were not added to one eppendorf tube was used. $(40 \mu \mathrm{l})$ of the master mix were put into each tube containing the first time amplified (VP7 cDNA) and ran for (35 cycles) in thermo cycler. The samples were then ran in (2\%) agarose gel and viewed under UV light along side with (100 bp) ladder.

Table-2: Oligonucleotide primer for G-typing by nested PCR

\begin{tabular}{|l|l|l|l|}
\hline Genotype & Position & Primer & Sequence (5'-3') \\
\hline GI & $314-335$ & aBT1 & CAA GTA CTC AAA TCA ATG ATG G \\
\hline G2 & $411-435$ & aCT2 & CAA TGA TAT TAA CAC ATT TTC TGT G \\
\hline G3 & $689-709$ & aET3 & CGT TTG AAG AAG TTG CAA CAG \\
\hline G9 & $757-776$ & aFT9 & CTA GAT GTA ACT ACA ACT AC \\
\hline
\end{tabular}

\section{RESULTS}

A total of (150) children were included in this study the majority of children $(62.6 \%)$ were males and $(37.4 \%)$ were females. Their mean age was (13 months) range 2 months to 5years, more than one half were within the age group (1-12 month). The majority of the children $(83.3 \%)$ previously received rotavirus vaccine and only $(16.7 \%)$ were not vaccinated.

Rotavirus was detected in stool of $42(28.7 \%)$ out of 150 total children. The study revealed that the percentage of (Rotavirus Ag positive) children was $(29.3 \%)$ in males which is nearly equal to the percentage of Rotavirus Ag positive children in females $(26.6 \%)$ but this difference in gender was not found to be significant statistically (Table-3).

The current study showed that the highest percentage of infection by rotavirus was in age group of
(13-24 months) where (35.5\%) of cases were positive and the lowest percentage was observed in age group of more than (2 years), but this difference in age group was not found to be significant statistically (Table-4).

Regarding vaccination only (23.4\%) of vaccinated children against rotavirus were infected with rotavirus infection in comparison to $(52 \%)$ of children not vaccinated were infected with rotavirus infection, this finding was found to be statistically highly significant (Table-5).

The most common G-genotypes identified were G2 $(45.2 \%), \mathrm{G} 1(28.5 \%), \mathrm{G} 3(9.5 \%)$ and G9 $(4.8 \%)$ (Table-4). G2 was the predominant type that circulates among vaccinated children, while G1 was the predominant genotype that circulates among nonvaccinated children (Table-6).

Table-3: Distribution of Rotavirus Ag positive children $<\mathbf{5}$ year according to gender

\begin{tabular}{|l|l|l|l|l|}
\hline \multirow{2}{*}{ Gender } & \multirow{2}{*}{ Total tested } & \multicolumn{3}{|l|}{ Rotavirus antigen positive } \\
\cline { 3 - 4 } & & Frequency & Percent \% & Sig.(2-sided) \\
\hline Male & 94 & 27 & $28.7 \%$ & \multirow{2}{*}{0.7} \\
\hline Female & 56 & 15 & $26.6 \%$ & \\
\hline Total & 150 & 42 & $28 \%$ & \\
\hline \multicolumn{4}{|c|}{ P value $=0.05$}
\end{tabular}

Table-4: Distribution of Rotavirus Ag positive (ELISA) children $<5$ year by age group

\begin{tabular}{|l|l|l|l|l|}
\hline Age group (Months) & \multirow{2}{*}{ Total tested } & \multicolumn{3}{|l|}{ children positive for Rotavirus antigen } \\
\cline { 3 - 5 } & & No & Percent \% & \multirow{2}{*}{ Sig.(2-sided) } \\
\hline $1-12$ & 85 & 23 & $27 \%$ & \multirow{2}{*}{0.2} \\
\hline $13-24$ & 45 & 16 & $35.5 \%$ & \\
\hline More than 24 & 20 & 3 & $15 \%$ & \\
\hline Total & 150 & 42 & $28 \%$ & \\
\hline
\end{tabular}


Table-5: Distribution of Rotavirus Ag positive children $<5$ year according to vaccination status

\begin{tabular}{|l|l|l|l|l|}
\hline vaccination status & \multirow{2}{*}{ Total tested } & \multicolumn{3}{|c|}{ Rotavirus antigen positive } \\
\cline { 3 - 4 } & & Frequency & Percent \% & Sig.(2-sided) \\
\hline Vaccinated & 125 & 29 & $23.2 \%$ & \multirow{2}{*}{0.006} \\
\hline Non vaccinated & 25 & 13 & $52 \%$ & \\
\hline Total & 150 & 42 & $28 \%$ & \\
\hline \multicolumn{4}{|c}{ P value $=0.05$} \\
\hline
\end{tabular}

Table-6: The pattern of Rotavirus G-genotype among rotavirus Ag positive children

\begin{tabular}{|l|l|l|}
\hline Genotype & Frequency & Percent \% \\
\hline G2 & 19 & $45.2 \%$ \\
\hline G1 & 12 & $28.5 \%$ \\
\hline G3 & 4 & $9.5 \%$ \\
\hline G9 & 2 & $4.8 \%$ \\
\hline Un typable & 5 & $12 \%$ \\
\hline Total & 42 & $100 \%$ \\
\hline
\end{tabular}

\section{DISCUSSION}

In the current study rotavirus was found in stool of $(28 \%)$ of children presenting with diarrhea to Mohammed Alamin Hamid Pediatric Hospital. The frequency of rotavirus detection is lower than that obtained by [9], who denoted that (34.5\%) of participants shed rotavirus in feces. Reports from other countries have nearly shown that rotaviruses have been present in similar high rates in symptomatic infants less than (5 years) old [10]. Our result is lower than those reported from other countries including India 36.9\% [11], Denmark 39.9\% [12], Greece 40\% [13], 47\% China [10], Bangladesh 40\% [14], Thailand 43.6\% [15], Turkey 36.1\% [16], Pakistan 34\% [17], Jordan 33\% [18], Kuwait 40\% [19] and many towns in Iran as Tehran 35\% [20], Jahrom 46.2\% [21], Zanjan 31.5\% and Isfahan $30.8 \%$ [22], although higher than that figures reported from Venezuela $21.3 \%$ [23]. In addition, according to the WHO-coordinated global Rotavirus surveillance network, global rate of rotavirus detection among (48) countries was $40 \%$ [24].

The study declared that the frequency of rotavirus related diarrhea is nearly equal in males $(28.7 \%)$ to that of females $(26.6 \%)$ which are statistically insignificant. This finding disagrees with that obtained by [9], who reported that the frequency of rotavirus associated diarrhea was higher among males $(61.6 \%)$ than females $(38.4 \%)$. Different results reported from Cameroon were in agreement with our result in which denoted that no significant statistical difference between the prevalence of rotavirus infection among males and females [1].

The frequency of rotavirus detection in stool was insignificantly higher among the age group (1-12 months). (35.5\%) compared to the other age groups ( $\mathrm{P}$ value $=0.2)$. This is in accordance with the result of study done by Valentine and his co. workers, who found that the highest prevalence of rotavirus was among the age group (0-12 months) [1]. Study conducted in 2014 reported a lower prevalence of rotavirus diarrhea $(32 \%)$ among children between the age of (7-11 month) and (29.6\%) among the age group (1-6 month).

The current study revealed that the majority of G-genotypes circulating among the study population were G2 (45\%), G1 (29\%), G3 (10\%) and G9 (4\%). G2 was the main common genotype followed by G1 and the least circulating genotype was G9. These findings were in disagreement with that obtained by Luana and his colleagues, who reported that G1 was the most frewuent genotype, and it has been detected in percentages ranging from (36 to 74\%) in various regions of the globe [6]. Santos and his colleagues revealed that $79 \%$ of all analyzed samples in Salvador were G9 [25]. Similar results were also reported in Goiás, where Costa and his colleagues found $34 \%$ of G9 rotavirus infections.

In this study the prevalence of rotavirus diarrhea was found to be significantly higher among non-vaccinated children than vaccinated children $(52 \%$ vs. 23\%). These findings indicate that rotavirus vaccination reduced the transmission of the virus but not prevent the occurrence. A study done in USA in 2011 reported a decline in rotavirus transmission after introduction of rotavirus vaccine, however the degree of reduction in prevalence was higher than what was found in that study [26].

Common circulating G-genotypes among vaccinated children were G2 (55\%), G1 (17\%), G3 (13\%), and G9 (3\%), in comparison with non vaccinated children where common G-genotypes were G1 (54\%), G2 (23\%), G9 (8\%), and G3 (0\%). A prominent decrease in G1 type was observed among vaccinated children which reflect effective vaccination; however there is increase in G2 type among nonvaccinated children. These findings were in accordance with that obtained by [27] who revealed that the most prevalent G-genotype among vaccinated children was G2 genotype. 
The rate of rotavirus detection in stool specimen was found to be significantly higher among children with vomiting compared to those with no vomiting $(\mathrm{RR}=1.5)$. Fever was not found to be significantly associated with rotavirus antigen positively $(\mathrm{RR}=0.5)$.

\section{CONCLUSION}

The study concluded that (G1 genotype) is the most prevalent G-genotype among non-vaccinated children ( $<5$ years) old and $(\mathrm{G} 2)$ is the most prevalent (G-genotype) among vaccinated childreninfants less than five years. The study highlights the presence of G3 $(12 \%)$ and G9 $(4.8 \%)$ rotavirus strains. These data will be applied for making an develop decision about the introduction of rotavirus vaccine in Sudan and provides baseline data for vaccine studies in future.

\section{REFERENCES}

1. Valentine, N., Achidi, E., Gonsu, H, Lyonga, E., Mathew, D., Krisztian, B., \& Obama, A. (2012). Epidemiology of rotavirus diarrhea in children under 5 years in Northern Cameroon. The Pan African Medical Journal, 11:73.

2. Yasutaka, H., \& Albert, Z. (2000). Rotavirus Serotypes: Classification and Importance in Epidemiology, Immunity, and Vaccine Development. J Health Popul Nutr, 18(1):5-14.

3. Christabel, C., Kwamena, W., Sagoe, H., Richard, H., Julius, A., \& Mingle, G. (2012). Prevalence of severe acute rotavirus gastroenteritis and intussusceptions in Ghanaian children under 5 years of age. J Infect Dev C tries, 6(2):148-155.

4. Carla, I., Alice, C., Veridiana, M., \& Maria, L. (2007). G and P rotavirus genotypes in stool samples from children in Teresina, State of Piauí. Revista da SociedadeBrasileira de Medicina Tropical, 40(4):381-384.

5. Jeevan, B., William, S., Jatan, B., Sarmila, T., Jyoti, R., Ganga, R., \& Chandesh, W. (2012). Prevalence of group A genotype human rotavirus among children with diarrhoea in Nepal. WHO South-East Asia Journal of Public Health, 1(4):432-440.

6. Luana, S., Joana, D., Yvone, B., Rosa, H., \& Alexandre, D. (2010). Molecular characterization of G1 human rotaviruses detected in children from Belém, Pará, Brazil. Rev Pan-Amaz Saude, 1(1):125-130.

7. Isidore, J., Bonkoungou, S., Idrissa, S., Fide, T., Sheick, O., Fabienne, B, Kaisa, H., Alfred, S., Nicolas, B., \& George, E. (2000). Genotype Diversity of Group A Rotavirus Strains in Children With Acute Diarrhea in Urban Burkina Faso. Journal of Medical Virology, 83:1485-1490.

8. Anita, C., Mayank, S., Anju, S., \& Vikas, V. (2010). Distribution of human rotavirus $G$ and $P$ Genotypes in a hospital setting from Northern India. Southeast Asian J Trop Med Public Health, 41(5):1145-1152.
9. Brandt, C., Kim, H., \& Rodriguez, W. (1983). RNA-electrophoresis as a typing method for nosocomial rotavirus infection in a special-care baby unit. Journal of Hospital Infection, 4(13): 367-375.

10. Li, D. D., Yu, Q. L., Qi, S. X., Xie, Y., Zhang, Q., \& Cui, S. X. (2010). Study on the epidemiological of rotavirus diarrhea in Lulong in 2008-2009. Zhonghua Shi Yan He Lin Chuang Bing Du XueZaZhi, 24(1):2-4.

11. Chakravarti, A., Chauhan, M. S., Sharma, A., \& Verma, V. (2010). Distribution of human rotavirus $\mathrm{G}$ and $\mathrm{P}$ genotypes in a hospital setting from Northern India. Southeast Asian J Trop Med Public Health, 41(5):1145-52.

12. Fischer, T. K., Rungoe, C., Jensen C. S., Breindahl, M., Jorgensen, T. R., \& Nielsen, J. P. (2009). The burden of rotavirus disease in Denmark. Pediatr Infect Dis J, 30(7): 126-129.

13. Koukou, D., Grivea, I., Roma, E., Tsioni, H., Trimis, G., \& Galanakis, E. (2011). Frequency, clinical characteristics, and genotype distribution of rotavirus gastroenteritis in Greece (2007-2008). J Med Virol, 83(1):165-9.

14. Paul, S. K., Hossain, M. A., Mahmud, M. C., Ahmed, S., Hossain, M. A., \& Nandi A. K. (2011). Instability of human rotavirus $G$ genotypes circulating in a rural area of Bangladesh. Mymensingh Med J, 20(1):1-8.

15. Sungkapalee, T., Puntukosit, P., Eunsuwan, O., Theamboonlers, A., Chongsrisawat, V., \& Poovorawan, Y. (2006). Incidence and clinical manifestations of rotavirus infection among children with acute diarrhea admitted at Buri Ram Hospital, Thailand. Southeast Asian J Trop Med Public Health, 37(6):1125-31.

16. Kilic, I. H., Ozaslan, M., Karsligil, T., Karagoz, I. D., \& Zer, Y. (2007). Investigation of diarrhea agents less than 5 years of age in summer in Gaziantep/ Turkey. Pak J Biol Sci, 10(17):2915-9.

17. Alam, M. M., Khurshid, A., Shaukat, S., Suleman, R. M., Sharif, S., \& Angez, M. (2013). Epidemiology and genetic diversity of rotavirus strains in children with acute gastroenteritis in Lahore, Pakistan. PLoS One, 8(6):10-13.

18. Youssef, M., Shurman, A., Bougnoux, M., Rawashdeh, M., Bretagne, S., \& Strockbine, N. (2000). Bacterial, viral and parasitic enteric pathogens associated with acute diarrhea in hospitalized children from northern Jordan. FEMS Immunol Med Microbiol, 28(3):257-263.

19. Sethi, S. K., Al-Nakib, W., Khuffash, F. A., \& Majeed, H. A. (1984). Acute diarrhoea and rotavirus infections in young children in Kuwait. Ann Trop Paediatr, 4(2):117-21.

20. Kargar, M., Zaree, B., \& Tabatabaee, H. (2007). Genotyping of VP7 protein with Nested RT-PCR in children hospitalized in Tehran [Persian]. $J$ Infect Trop Dis, 12(39):11-7. 
21. Kargar, M., Akbarizadeh A. R., \& Yaghoubi, R. (2010). Molecular and serological evaluation of group A rotaviruses isolated from children with diarrhea admitted to Jahrom hospitals with RT PCR technique. Shahrekord J Med Sci, 12(3):1521.

22. Kazemi, A., Zomorosi Soufiani, A. R., \& Esmaeelzadeh, A. R. (2006). Comparison of clinical and laboratory findings in acute gastroenteritis caused by rotavirus and other causes among hospitalized children 2 months to 5 years in 2004 [Persian]. Zanjan J Med Sci, 14(57):32-8.

23. Vizzi, E., Pineros, O., Gonzalez, G. G., Zambrano, J. L., Ludert, J. E., \& Liprandi, F. (2011). Genotyping of human rotaviruses circulating among children with diarrhea in Valencia, Venezuela. J Med Virol, 83(12):2225-32.
24. Greenberg, H. B., \& Estes, M. K. (2013). Rotaviruses. In: Knipe DM, Howley PM editors. Fields virology. 6th ed. Philadelphia: Lippincott Williams \& Wilkins, a Welters Kluwer business, 1347-401.

25. Santos, N., \& Hoshino, Y. (2005). Global distribution of rotavirus serotypes/genotypes and its implication for the development and implementation of an effective rotavirus vaccine. Rev Med Virol, 15(1):29-56.

26. Jennifer, E., Aaron, T., Jacqueline, E., Margaret, M., Manish M., Fangjun, Z., \& Umesh, D. (2011). Rotavirus Vaccine and Health Care Utilization for Diarrhea in U.S. Children. New England Journal Med, 365:1108-17.

27. Gura, V., \& Rambod, E. (2010). U.S. Patent No. 7,645,253. Washington, DC: U.S. Patent and Trademark Office. 